\title{
Publisher Correction: Statistical modeling of RNA structure profiling experiments enables parsimonious reconstruction of structure landscapes
}

Hua $\mathrm{Li}^{1} \&$ Sharon Aviran (i) ${ }^{1}$

Correction to: Nature Communications https://doi.org/10.1038/s41467-018-02923-8, published online 09 February 2018

The originally published version of this Article contained an error in Figure 2, due to a typesetting error. Panels $d$ and e were positioned such that the locations of the mutations in panel $\mathrm{d}$ did not align correctly with the corresponding nucleotides in the reactivity profile in panel e. This has now been corrected in both the PDF and HTML versions of the Article.

Published online: 13 March 2018

\begin{abstract}
(c) (i) Open Access This article is licensed under a Creative Commons Attribution 4.0 International License, which permits use, sharing, adaptation, distribution and reproduction in any medium or format, as long as you give appropriate credit to the original author(s) and the source, provide a link to the Creative Commons license, and indicate if changes were made. The images or other third party material in this article are included in the article's Creative Commons license, unless indicated otherwise in a credit line to the material. If material is not included in the article's Creative Commons license and your intended use is not permitted by statutory regulation or exceeds the permitted use, you will need to obtain permission directly from the copyright holder. To view a copy of this license, visit http://creativecommons.org/licenses/by/4.0/.
\end{abstract}

(c) The Author(s) 2018

\footnotetext{
${ }^{1}$ Department of Biomedical Engineering and Genome Center, University of California at Davis, Davis, CA 95616, USA. Correspondence and requests for materials should be addressed to S.A. (email: saviran@ucdavis.edu)
} 